\title{
In-situ Moisture Conservation in Rainfed Stressed Regions for Increasing Productivity of Cotton Crop
}

\author{
P. D. Vekaria, V. D. Vora*, T. J. Patel, J. T. Patel, G. R. Sharma, \\ H. R. Vadar and D. S. Hirpara \\ Dry Farming Research Station, Junagadh Agricultural University, \\ Targhadia (Gujarat)-360 003, India \\ *Corresponding author
}

\author{
A B S T R A C T
}

\begin{tabular}{|l|}
\hline K e y w o r d s \\
In-situ moisture \\
conservation, \\
Mulching, Cotton, \\
Ridge and furrow, \\
Yield
\end{tabular}

\begin{abstract}
A field experiment was conducted during kharif season of 2015-16 to 2017-18 to study the in-situ moisture conservation in rainfed region for increasing productivity of cotton crop at Main Dry Farming Research Station, Junagadh Agricultural University, Targhadia of North Saurashtra Agro climatic Zone of Gujarat. The experiment comprising of three main plot treatments (in-situ moisture conservation practices) and three sub plot treatments (Mulching practices) laid out in split plot design with three (3) replications. Significantly higher soil moisture content was observed due to ridge and furrow practice $\left(\mathrm{T}_{1}\right)$ and plastic mulch $\left(\mathrm{M}_{1}\right)$ and it was remained at par with broad bed and furrow $\left(\mathrm{T}_{2}\right)$ and straw mulch, respectively. Seed cotton and stalk yield was also significantly higher in ridge and furrow practice $\left(\mathrm{T}_{1}\right)$ and plastic mulch $\left(\mathrm{M}_{1}\right)$ and it was remained at par with broad bed and furrow $\left(\mathrm{T}_{2}\right)$. Same trend observed in rain water use efficiency. Economic analysis revealed that the net profit and $\mathrm{B}: \mathrm{C}$ ratio was recorded higher under ridge and furrow system with plastic mulch (25 micron) compared to control. Interaction effect of in-situ moisture conservation practices and mulching practices were found non significant for all the parameters.
\end{abstract}

\section{Introduction}

Cotton is important commercial crop of Gujarat. In saurashtra region cotton is the second most grown crop after groundnut. Gujarat is the single largest cotton producer state with $36 \%$ (101 lakh bales) of the total national production from the area about 25.00 lakh hectares. Saurashtra account $65 \%$ of the state and contributes $68 \%$ in the total production of the state. However, cotton productivity in rainfed areas is still below the potential productivity, mainly due to erratic distribution of rainfall and moisture stress during crop growth period which may results in partial failure of crops. Therefore there is a need of simple in-situ moisture conservation practices that meet out the adverse effect of moisture stress in standing crop.

In-situ moisture conservation practices viz., ridges and furrows + mulch, imparted beneficial effect on cluster bean for getting good growth and higher yields; which 
subsequently led to higher net returns and B: C ratio (Allolli et al., 2008). Mulching reduces the deterioration of soil by way of preventing the runoff and soil loss, minimizes the weed infestation and checks the water evaporation. Thus, it facilitates for more retention of soil moisture and helps in control of temperature fluctuations, improves physical, chemical and biological properties of soil, as it adds nutrients to the soil and ultimately enhances the growth and yield of crops. Further, reported that mulching boosts the yield by 50-60 per cent over no mulching under rainfed situations (Dilipkumar et al., 1990).

\section{Materials and Methods}

The experiment on in-situ moisture conservation in rainfed region for increasing productivity of cotton crop was conducted at Main Dry Farming Research Station, JAU, Targhadia. The soil of experimental field was black and clayey in texture, $\mathrm{pH} 8.15$, organic carbon $0.527 \%$ and EC $0.28 \mathrm{mmhos} / \mathrm{cm}$ and available $\mathrm{P}_{2} \mathrm{O}_{5} 32.6 \mathrm{~kg} / \mathrm{ha}$, available $\mathrm{K}_{2} \mathrm{O} 460$ $\mathrm{kg} / \mathrm{ha}$ at $0-15 \mathrm{~cm}$ depth of soil. The physical measure of soil are viz., field capacity $(33.8 \%)$, wilting point $(17.0 \%)$, infiltration rate $(10.4 \mathrm{~mm} / \mathrm{hr})$, apparent specific gravity (1.34 g/cc), maximum WHC (47.0\%).

The experiment was laid out on split plot design with three replications. The treatments incorporated in-situ moisture conservation practices as main plot treatment are $\mathrm{T}_{1}$ Ridge and furrow, $\mathrm{T}_{2}$-Broad bed and furrow and $\mathrm{T}_{3}-$ Control and sub plot treatment include mulching practices $\mathrm{M}_{1}$ - Plastic mulch (25 micron), $\mathrm{M}_{2}$ - Straw mulch @ $5 \mathrm{t} / \mathrm{ha}$ and $\mathrm{M}_{3}-$ Control. In-situ moisture conservation practices were applied after 20 DAS and mulching were applied after withdrawn of monsoon in the month of September (38 to 39 std. week). Gross plot size-5.40 x $4.80 \mathrm{~m}$ and net plot-3.60 x $2.40 \mathrm{~m}$. The spacing and seed rate are $120 \mathrm{x} 45 \mathrm{~cm}$ and $2.5 \mathrm{~kg} / \mathrm{ha}$ respectively. The crop was fertilized with 80:00:00 kg NPK/ha.

\section{Results and Discussion}

\section{Seed cotton and stalk yield}

\section{Effect of in-situ moisture conservation practices $(T)$}

The pooled result of three years presented in (Table 1) revealed that significantly higher seed cotton yield (2141 kg/ha) and stalk yield (3646 kg/ha) were obtained in Ridge and furrow practices over the control, but both parameters seed cotton yield and stalk yield were at par with broad bed and furrow practices. Similar results were reported by S. Ganapathi et al., (2018).

\section{Effect of Mulching Practices (M)}

Results presented in table 1 showed that seed cotton and stalk yield were significantly affected due to mulching practices. Significantly higher seed cotton yield (2135 $\mathrm{kg} / \mathrm{ha}$ ) was produced under application of plastic mulch as compared to control, but it was remained at par with straw mulch (1994 $\mathrm{kg} / \mathrm{ha}$ ). The similar trend was observed for cotton stalk yield $(3645 \mathrm{~kg} / \mathrm{ha})$ in pooled results. These findings are close with findings of Prajapati et al., (2018) and Dilipkumar et al., (1990).

Interaction effect of in-situ moisture conservation and mulching practices ( $\mathrm{T} X$ M)

Interaction effect of in-situ moisture conservation and mulching practices (T X M) was found non-significant in pooled results in respect of seed cotton yield and stalk yield (Table 1). 
Table.1 Effect of In-situ moisture conservation practices on yield, soil moisture content, RWUE and economics of cotton

\begin{tabular}{|c|c|c|c|c|c|c|c|c|c|}
\hline $\begin{array}{l}\text { Sr. } \\
\text { No } \\
.\end{array}$ & Treatment & $\begin{array}{c}\text { Seed cotton } \\
\text { yield } \\
(\mathrm{kg} / \mathrm{ha})\end{array}$ & $\begin{array}{c}\text { Stalk } \\
\text { yield } \\
\text { (kg/ha) }\end{array}$ & $\begin{array}{c}\text { Soil } \\
\text { moisture } \\
\text { content } \\
(\%)\end{array}$ & $\begin{array}{c}\text { Rain water use } \\
\text { efficiency } \\
\text { (kg/ha-mm) }\end{array}$ & $\begin{array}{l}\text { Gross return } \\
\text { (Rs./ha) }\end{array}$ & $\begin{array}{c}\text { Cost of } \\
\text { cultivation } \\
\text { (Rs./ha) }\end{array}$ & $\begin{array}{l}\text { Net returns } \\
\text { (Rs./ha) }\end{array}$ & $\begin{array}{l}\mathrm{B}: \mathrm{C} \\
\text { ratio }\end{array}$ \\
\hline A. & \multicolumn{9}{|c|}{ In-situ moisture conservation practices $(\mathrm{T})$ : Three } \\
\hline 1. & Ridge and furrow $\left(\mathrm{T}_{1}\right)$ & 2141 & 3646 & 24.38 & 5.22 & 115082 & 33033 & 82049 & 3.48 \\
\hline 2. & Broad bed and furrow $\left(\mathrm{T}_{2}\right)$ & 2043 & 3499 & 22.54 & 5.01 & 109824 & 32633 & 77191 & 3.37 \\
\hline \multirow[t]{4}{*}{3.} & Control $\left(\mathrm{T}_{3}\right)$ & 1788 & 3232 & 20.54 & 4.40 & 96201 & 32233 & 63968 & 2.98 \\
\hline & S. Em. \pm & 44 & 81 & 0.44 & - & - & - & - & - \\
\hline & C.D.at $5 \%$ & 135 & 251 & 1.36 & - & - & - & - & - \\
\hline & C.V.\% & 11.45 & 12.22 & 10.17 & - & - & - & - & - \\
\hline B. & \multicolumn{9}{|l|}{ Mulching practices (M): Three } \\
\hline 1. & $\begin{array}{l}\text { Plastic mulch (25 micron) } \\
\left(\mathrm{M}_{1}\right)\end{array}$ & 2135 & 3645 & 23.93 & 5.23 & 114764 & 34100 & 80664 & 3.37 \\
\hline 2. & Straw mulch $\left(\mathrm{M}_{2}\right)$ & 1994 & 3444 & 22.85 & 4.88 & 107205 & 32900 & 74305 & 3.26 \\
\hline \multirow[t]{3}{*}{3.} & Control $\left(\mathrm{M}_{3}\right)$ & 1843 & 3289 & 20.67 & 4.52 & 99139 & 30900 & 68239 & 3.21 \\
\hline & S.Em. \pm & 39 & 62 & 0.42 & - & - & - & - & - \\
\hline & C.D.at $5 \%$ & 113 & 177 & 1.19 & - & - & - & - & - \\
\hline C. & \multicolumn{9}{|l|}{ Interaction Effect of TxM: } \\
\hline & S.Em. \pm & 68 & 107 & 0.72 & - & - & - & - & - \\
\hline & C.D.at $5 \%$ & NS & NS & NS & - & - & - & - & - \\
\hline & C.V.\% & 10.30 & 9.26 & 9.60 & - & - & - & - & - \\
\hline
\end{tabular}




\section{Soil moisture content (\%)}

\section{Effect of in-situ moisture conservation practices $(\mathrm{T})$}

The pooled result revealed that soil moisture content (\%) was significantly affected due to in-situ moisture conservation practices. Significantly higher soil moisture content (\%) was recorded under ridge and furrow practice (24.38\%) followed by broad bed and furrow practice $(22.54 \%)$ as compared to control (20.54\%). These results confirm the findings of Vekariya et al., (2015), Patode et al., (2017).

\section{Effect of Mulching Practices (M)}

The soil moisture content (\%) was significantly affected due to mulching practices during all the three years of experimentation and pooled results (Table 1). Significantly higher soil moisture content $(\%)$ was recorded under application of plastic mulch $(23.93 \%)$ as compared to control (20.67\%), but it was remained at par with straw mulch $(22.85 \%)$ in pooled results. The findings are close with findings of Chen and Katan (1980) and Lalitha et al., (2010).

Interaction effect of in-situ moisture conservation and mulching practices ( $T$ X M)

Interaction effect of in-situ moisture conservation and mulching practices (T X M) was found non-significant during all the three years and pooled results in respect of soil moisture content $(\%)$.

\section{Rain water use efficiency}

Rain water use efficiency (Table 1) was also calculated under different treatments of in-situ moisture conservation and mulching practices. Maximum rain water use efficiency was recorded in ridge and furrow practice $(5.22 \mathrm{~kg} / \mathrm{ha}-\mathrm{mm})$ followed by broad bed and furrow practice $(5.01 \mathrm{~kg} / \mathrm{ha}-\mathrm{mm})$ and application of plastic mulch $(5.23 \mathrm{~kg} / \mathrm{ha}-\mathrm{mm})$ followed by straw mulch $(4.88 \mathrm{~kg} / \mathrm{ha}-\mathrm{mm})$ under in-situ moisture conservation and mulching practices, respectively in pooled results.

\section{Economics}

Economics of different treatments was worked out on the basis of pooled results and presented in Table 1. The data indicated that the highest gross return (Rs. 115082/ha), net return (Rs. 82049/ha) and B: C ratio (3.48) was obtained by the ridge and furrow practice $\left(\mathrm{T}_{1}\right)$ followed by broad bed and furrow practice $\left(\mathrm{T}_{2}\right)$ (Rs.109824, 77191/ha and 3.37) as compared to control $\left(\mathrm{T}_{3}\right)$ (Rs. 96201, 63968/ha and 2.98) under in-situ moisture conservation practices, similar results were obtained by Basediya et al., (2018).

While in mulching practices, application of plastic mulch $\left(\mathrm{M}_{1}\right)$ gave the maximum gross return (Rs.114764/ha), net returns (Rs.80664/ha) with B: C ratio of 3.37 followed by straw mulch $\left(\mathrm{M}_{2}\right)$ (Rs.107205, 74305/ha and 3.26) as compared to control $\left(M_{3}\right)$ (Rs. 99139, 68239/ha and 3.21). Similar results were also observed by RajuLalBhardwaj (2013).

From the results of experiment it is concluded that growing Bt. cotton at the distance of 120 $\mathrm{cm} \times 45 \mathrm{~cm}$ with ridge and furrow between 2 rows OR broad bed $(180 \mathrm{~cm}$ width) and furrow $(60 \mathrm{~cm})$ with 2 rows at 20 days after sowing and apply plastic mulch (25 micron) OR straw mulch@5t/ha at withdrawn of monsoon in the month of September (38 to 39 Std. week) for gave higher productivity and maximum net returns as well as maximum insitu moisture conservation and rain water use efficiency under dry farming conditions. 


\section{References}

Allolli, T. B., Hulihalli, U. K and Athani, S.I., (2008). Influence of in situ moisture conservation practices on the performance of Dry land cluster bean. Karnataka Journal Agriculture Science. 21(2): 250-252.

Basediya, A.L., Mishra Sunita., Gupta rajesh., kumar, P and Basediya S. S., (2018). Performance of Ridge and Furrow System on the Growth and Yield Attribution of Soybean in Barwani District of M.P. India. Int.J.Curr.Microbiol.App.Sci. 7(8): 499-505.

Chen, Y and Katan, J., (1980). Effect of solar heating of soils by transparent polyethylene mulching on their chemical properties. Soil Science, 130: 271-277.

Dilip Kumar G., Sachin S. S and Rajesh Kumar., (1990). Importance of mulch in crop production, Indian J. Soil Cons., 18: 20-26.

Ganapathi, S., Bharathi, S., SreeRekha, M and Jayalalitha, K., (2018). Effect of insitu moisture conservation practices on soil moisture content of rainfed Bt. Cotton (Gossypium hirsutum L.). Int.J.Curr.Microbiol.App.Sci., 7(10): 2033-2036.

Lalitham M., V. Kasthuri Thilagam, N. Balakrishnan and Mostafa Mansour (2010). Effect of plastic mulch on soil properties and crop growth- A review. Agric. Rev., 31 (2): 145-149.

Padmanabhan, M. V., (2008). Assessing effectiveness of soil and water conservation practices by EPIC model. Technological advances in conservation of natural resources in rainfed agriculture, CRIDA, Hyderabad, Pp. 290-298.

Patode, R. S., Nagdeve, M. B., Ganvir, M. M. and Gabhane, V. V.,(2017).Evaluation of In-situ Moisture Conservation Practices for Sustainable Productivity of Major Crops in Vidarbha Region. Int.J.Curr.Microbiol.App.Sci., $\quad$ 6(10): 261-268.

Prajapati, G.V., (2017). Influence of Irrigation Regimes, Frequency and Mulching on Productivity of Bt. Cotton. Madras agricultural journal, 104(7-9): 242246.

Raju Lal Bhardwaj (2013). Effect of mulching on crop production under rainfed condition-A review. Agri. Reviews, 34(3): 188-197.

Vekariya P.D., Sanepara D.P., Limbasia B.B., Sharma G.R., Akbari K.N. (2015). Effect of different size of broad bed and furrow on runoff and soil loss and productivity of groundnut (Arachis hypogea L.) under rainfed conditions. International Journal of Bio-Resource and Stress Management, 6(3): 316321.

\section{How to cite this article:}

Vekaria, P. D., V. D. Vora, T. J. Patel, J. T. Patel, G. R. Sharma, H. R. Vadar and Hirpara, D. S. 2020. In-situ Moisture Conservation in Rainfed Stressed Regions for Increasing Productivity of Cotton Crop. Int.J.Curr.Microbiol.App.Sci. 9(09): 777-781. doi: https://doi.org/10.20546/ijcmas.2020.909.097 